\title{
Induction of Genetic Variability and Isolation of Mutants in Tuberose (Polianthes tuberosa L)
}

\author{
Pooja Kainthura and Ranjan Srivastava* \\ Department of Horticulture \\ G.B. Pant University of Agriculture \& Technology \\ Pantnagar-263 145, India
}

\begin{abstract}
The effect of various mutagenic treatments on vegetative and floral characters of different cultivars of tuberose (Polianthes tuberosa L) was studied and isolation of promising mutants were done. The experimental material comprised of four tuberose varieties viz., Kalyani Single, Kalyani Double, Suvasini and Prajwal, treated with two doses each of gamma rays viz., $(0.5 \mathrm{Kr}, 1.5 \mathrm{Kr}), \mathrm{X}$-rays $(0.6 \mathrm{Kr}, 1.2 \mathrm{Kr})$ and Ethyl Methyl Sulphonate ( 0.1 per cent, 0.2 per cent) along with the untreated sample (control). Results indicated that the mutagenic treatments at lower doses had significant stimulative effect on some parameters i.e., sprouting percentage, days taken to sprouting, whereas most of the parameters showed a decrease from desired levels i.e., survival rate, leaf length, number of spikes/plant \& florets/spike, flowering duration and vase life. Higher doses of all mutagens were detrimental for vegetative and floral characters. Six mutants were also obtained exhibiting variation in plant height [cv. Prajwal treated with EMS (0.2\%)], increase in number of petals per floret (cv. Prajwal treated with $1.2 \mathrm{Kr} X$-rays), fusion of two floret into one [cv. Suvasini and cv. Prajwal treated with EMS (0.2\%)], decrease in number of whorl per floret [cv. Suvasini with $1.2 \mathrm{Kr}$ gamma rays treatment] and presence of stamen in double type cultivar (cv. Suvasini with plant treated with $1.2 \mathrm{Kr} \mathrm{X}$-rays).
\end{abstract}

Keywords: EMS, floral characters, Tuberose, X-rays, $\gamma$-rays

\section{INTRODUCTION}

Floriculture is a dynamic industry and demands for novelty in existing crops and products. Development of new cultivars through conventional or modern techniques has been a prime objective in commercial floriculture. New colour, earliness in flowering, stem length, number of flowers, plant architecture, resistance to abiotic and biotic stresses, productivity and keeping quality are the main attributes required in new cultivars. These new cultivars in existing crops could be produced by the introduction, hybridization and molecular techniques such as genetic engineering through the alternation of characteristics such as flower colour and plant form. Over the past 50 years, the use of induced mutations (through irradiation and chemical agents) has also played a major role in the development of superior crop varieties (Datta, 1997). Mutation is a method by which novelty can be created in an already well established cultivar. There is no visual difference between artificially produced or induced mutants and spontaneous mutants found in nature (Broertjes, 1968).

\footnotetext{
* Corresponding author: ranjansrivastava25@gmail.com
} 
Extensive research and development activities on mutation breeding has been carried out for the past 50 years to enhance the genetic diversity in the germplasm of food and industrial crops and these efforts have resulted in the official release of over 2,700 new crop varieties in some 170 species. These mutants have created tremendous economic impact in Agriculture throughout the world (http://www-mvd.iaea.org). Thus, mutation induction has proven to be a workable, sustainable, highly-efficient, environmentally acceptable, flexible, unregulated, non-hazardous and a low-cost technology to enhance crop improvement.

Ornamental plants appear to be the ideal system for application of mutation induction technique as many characters of economic importance i.e. flowering traits or growth habit are easily monitored after mutagenic treatment. Any change in the dominant genes are easily expressed in the first generation and thus, the selection of mutant of directly perceptible characters like flower colour, shape, size etc., is generally very easy and can directly be put to commercial use. Furthermore, many ornamental species are heterozygous and are often propagated vegetatively thus, allowing the detection, selection and conservation of mutants within M1 generation (Van Hartan, 2002). In ornamentals, the first artificially induced commercial mutant cv. Faraday, a flower colour mutant in Tulipa hybrida was released in 1949 in The Netherlands by W. E. de Mol from X-ray irradiated bulbs of cv. Fantasy, following irradiation in 1936. A second flower colour mutant cultivar in tulip cv. Estella Rijnveld, was released by the same researcher in 1954 (Van Hartan, 2002).

Tuberose (Polianthes tuberosa L.) is a popular fragrant cut flower of the Tropical and Subtropical regions of India. There are very few cultivars of tuberose in production worldwide. In all the existing varieties, flower colour is limited to white, although some varieties show pinkish tinge at bud stage. To develop more variation in biotic and abiotic traits such as disease resistance, flower shape, vase life, etc. in tuberose, there is an urgent need of well planned breeding programmes using conventional and non-conventional breeding techniques.

There is limitation of conventional breeding methods involving hybridization in tuberose due to self incompatibility (Sreethramu et al., 2000). Mutation breeding appears to be a well standardized, efficient and cost-effective technique that can be exploited for the creation of novel ornamental cultivars of commercial importance in tuberose. Although mutation breeding is a random process, reports are available on classical mutagenesis combined with management of chimera and in vitro mutagenesis can be used for inducing genetic variation in already adapted modern genotypes resulting in developing new and novel varieties. The present study was carried out to assess the vegetative and floral characteristics of potential varieties of tuberose as influenced by different mutagens and doses used and to screen mutants of existing cultivars through mutation induced variation for desirable traits.

\section{METHODOLOGY}

The tuberose (Polianthes tuberose L.) cultivars Kalyani Single (V1), Kalyani Double (V2), Suvasini (V3) and Prajwal (V4) (Photo 1), which have been found promising for floral traits, were selected for the present investigation. Healthy and uniform bulbs of appropriate size $(1.5-2.0 \mathrm{~cm}$ in diameter) were used for mutagenic treatments and subsequent planting. The bulbs of selected cultivars were obtained from the germplasm maintained at the Model Floriculture Centre of G.B. Pant University of Agriculture \& Technology, Pantnagar, India. The bulbs were exposed to Gamma rays [1 Kr] (T1), Gamma rays [1.5 Kr] (T2), X-rays [0.6 $\mathrm{Kr}$ (T3), X-rays [1.2 Kr] (T4), EMS [0.1\%] (T5), EMS [0.2\%] (T6) and control (T7). The 
Gamma irradiation facility of the National Botanical Research Institute in Lucknow, India is equipped with Gamma chamber-900 with source of ${ }^{60} \mathrm{Co}$, X-ray machine of Department of Entomology of the G.B. Pant University of Agriculture \& Technology, Pantnagar, India were availed for treating the bulbs with physical mutagens. The bulbs of selected varieties were dipped and subjected to continuous shaking in freshly prepared solution of 0.1 and 0.2 per cent of EMS for 12 hours and then dried under shade before planting in the field.

The experiment was laid out in a Randomized Block Design. Eighty four plots of $1 \mathrm{~m} \mathrm{x} 1 \mathrm{~m}$ were laid out to accommodate the twenty eight treatments replicated three times. The bulbs were planted at a spacing of $30 \mathrm{~cm} \times 30 \mathrm{~cm}$ at a depth of 5-7 cm in April. The plants were maintained under uniform cultural conditions throughout the period of investigation.

\section{RESULTS AND DISCUSSION}

\section{Vegetative characters}

Data presented in Table 1 on plant height revealed that there was a significant effect of cultivars $(\mathrm{p}=1.14)$, mutagenic treatments $(\mathrm{p}=1.11)$ and their interaction $(\mathrm{p}=2.93)$ on plant height Plants treated with 0.2 per cent EMS (T6) gave the maximum mean plant height (26.1 $\mathrm{cm}$ per plant), which was significantly higher than the rest of the treatments while the minimum mean plant height $(22.3 \mathrm{~cm}$ per plant) was found in those treated with $1.5 \mathrm{Kr}$ gamma-rays (T2). Among interactions, the maximum $(29.5 \mathrm{~cm})$ plant height was found with 0.2 per cent EMS in cv. Prajwal (T6V4), which was statistically at par $(\mathrm{p}=2.93)$ with T2V2 $(29.3 \mathrm{~cm})$, T4V2 $(27.58 \mathrm{~cm})$, T1V4 $(27.0 \mathrm{~cm})$ and while the minimum plant height $(18.6$ $\mathrm{cm}$ ) was observed in cv. Suvasini with $0.5 \mathrm{Kr}$ gamma rays treatment (T1V3).

There was differential response of mutagenic treatment on plant height, which was highly influenced by the cultivar. With respect to the control, there was a slight increase in plant height in most of the cultivars after mutagenic treatment. Increase in plant height was marginally higher at increased doses (1.5 Kr gamma rays, $1.2 \mathrm{X}$-ray and 0.2 per cent EMS) compared to the lower doses of mutagenic treatment except in X-rays treatment. Ramesh et al. (2012) also reported an increase in plant height with the increase in dose of mutagen to a certain optimum level of the mutagenic dose. Fowler and Mac Queen (1972) hypothesized that most of the reported stimulatory effects of low doses of radiation was due to early modifications in axillary bud development and changes in the initial rate of floral differentiation

A perusal of data for number of leaves reveals that there is significant effect of mutagenic treatments. Among treatments, $0.5 \mathrm{Kr}$ gamma rays (T1) gave the highest number of leaves (47 per plant), which was significantly higher $(\mathrm{p}=1.23)$ than the rest of the treatments while the lowest number of leaves (38 per plant) was found in the 1.5 gamma rays (T2) treatment. Among the interactions, the highest number of leaves (59.73 per plant) was found with the untreated control of cv. Suvasini (T7V3), which was significantly higher $(p=2.45)$ than rest of the treatment combinations while the lowest number of leaves (32 per plant) was observed in cv. Suvasini with 0.2 per cent EMS (T6V3) treatment. The number of leaves per plant decreased in all cultivars with increased dose of mutagen irrespective of treatments when compared to the control. The decrease observed in the number of leaves per plant was lesser at lower dose as compared to higher doses of mutagenic treatment. A decrease in the number of leaves per plant with increase in dose of mutagen has been reported by Abraham and Desai (1976) in tuberose, Sobhana and Rajeevan (2003) in Dendrobium senile Reduction in 
the vegetative growth due to changes in auxin level or due to inactivation of auxins was hypothesized by Datta and Datta (1953) while studying the effect of high dosage of X-rays irradiation on inhibition of growth in rice (Oryza sativa L) seedlings. Gordon and Weber (1950) who reported of a decrease in auxin level in the leaves of Zea mays after 25 or 100 rads of X-rays concluded that destruction of enzyme system or inhibition of auxin synthesis due to irradiation could result in decrease in the vegetative growth of crops. Inhibition of mitotic activities and chromosome damage associated with secondary physiological damage could also be the cause for reduction in vegetative growth as reported by Sparrow (1961) who studied the cytological effects of ionisation of different plants.

Table 1. Effect of different mutagenic treatments on vegetative characters

\begin{tabular}{|c|c|c|c|c|c|c|c|c|c|c|}
\hline \multirow[t]{2}{*}{ Treatment } & \multicolumn{5}{|c|}{ Plant Height (cm) } & \multicolumn{5}{|c|}{ Number of leaves per plant } \\
\hline & $\mathbf{V}_{1}^{*}$ & $\mathbf{V}_{2}$ & $\mathbf{V}_{3}$ & $\mathbf{V}_{4}$ & Mean & $\mathbf{V}_{1}$ & $\mathbf{V}_{2}$ & $\mathbf{V}_{3}$ & $\mathbf{V}_{4}$ & Mean \\
\hline $\mathrm{T}_{1}^{*}$ & 20.9 & 24.7 & 18.6 & 27.0 & 22.8 & 44 & 39 & 54 & 52 & 47 \\
\hline $\mathrm{T}_{2}$ & 19.3 & 21.7 & 29.3 & 19.1 & 22.3 & 37 & 39 & 34 & 43 & 38 \\
\hline $\mathrm{T}_{3}$ & 23.8 & 25.5 & 19.9 & 20.4 & 22.4 & 36 & 44 & 42 & 42 & 42 \\
\hline $\mathrm{T}_{4}$ & 24.3 & 27.6 & 22.2 & 23.4 & 24.4 & 37 & 50 & 45 & 42 & 43 \\
\hline $\mathrm{T}_{5}$ & 23.6 & 28.8 & 21.7 & 24.5 & 26.7 & 51 & 47 & 44 & 42 & 46 \\
\hline $\mathrm{T}_{6}$ & 22.0 & 26.5 & 26.5 & 29.5 & 26.1 & 55 & 35 & 32 & 39 & 40 \\
\hline $\mathrm{T}_{7}$ & 22.1 & 26.4 & 26.4 & 24.7 & 24.9 & 43 & 39 & 60 & 42 & 44 \\
\hline \multirow[t]{2}{*}{ Mean } & 22.3 & 25.9 & 23.5 & 24.1 & 23.9 & 43 & 42 & 44 & 43 & 43 \\
\hline & & & \multicolumn{2}{|c|}{$\mathrm{CD}^{* *}(\mathrm{p}=0.05)$} & \multicolumn{2}{|c|}{$\mathrm{SE}^{* * *}$} & \multicolumn{2}{|c|}{$\mathrm{CD}(\mathrm{p}=0.05)$} & \multicolumn{2}{|l|}{ SE } \\
\hline \multirow{3}{*}{\multicolumn{3}{|c|}{$\begin{array}{l}\text { Varieties } \\
\text { Treatments } \\
\text { Interaction }\end{array}$}} & \multicolumn{2}{|c|}{1.46} & \multicolumn{2}{|c|}{0.52} & 0.93 & \multicolumn{2}{|c|}{0.33} & \\
\hline & & & \multicolumn{2}{|c|}{1.11} & 0.39 & & 1.23 & \multicolumn{2}{|c|}{0.43} & \\
\hline & & & \multicolumn{2}{|c|}{2.93} & 1.03 & & 2.45 & & & \\
\hline
\end{tabular}

* Refer to the materials and methods for the description of treatments and varieties; ${ }^{* *}$ Critical difference; ${ }^{* * *}$ Standard error of the mean

A significant effect of cultivars, mutagenic treatments and their interactions on chlorophyll content of leaves was apparent (Table 2). Among the treatments, 1.2 $\mathrm{Kr}$ Xrays (T4) resulted in the maximum chlorophyll content of leaf $\left(48.62 \mu \mathrm{g} \mathrm{cm}^{-2}\right)$, which was statistically at par $(\mathrm{p}=3.15)$ with T7 and T3 while the minimum chlorophyll content of leaf $\left(44.46 \mu \mathrm{g} \mathrm{cm}^{-2}\right)$ was found in plants treated with $1.2 \mathrm{Kr}$ gamma rays (T2). Among the interactions, the maximum chlorophyll content of leaf $\left(49.98 \mu \mathrm{g} \mathrm{cm}^{-2}\right)$ was found in cv. Prajwal with $0.6 \mathrm{Kr}$ $\mathrm{X}$-rays treated plants (T3V4) which was statistically at par with T7V4, T4V1, T4V3,T3V3, T7V2, T5V2,T4V2, T7V3, T5V3, T6V3, T4V4 and T1V1 while the minimum chlorophyll content of leaf $\left(42.33 \mu \mathrm{g} \mathrm{cm}^{-2}\right)$ was observed in cv. Prajwal with $1.5 \mathrm{Kr}$ gamma-rays (T2V4 $\mu \mathrm{g} \mathrm{cm}^{-2}$ ) treated plants. A significant variation in the chlorophyll content due to mutagenic treatment was also reported by Swaminathan (1964) in Triticum aestivum while comparing mutation induction in diploids and polyploids and Kolar et al. (2011) in Delphinium malabaricum (Huth) Munz, while studying gamma ray induced chlorophyll mutations. Variation in chlorophyll development seems to be controlled by many genes located on several chromosomes which could be adjacent to centromere and proximal segment of chromosome (Swaminathan, 1964).

Results presented in Table 2 also showed that 0.1 per cent EMS (T5) gave the maximum leaf length per plant $(23.2 \mathrm{~cm})$, which was statistically at par with T1, T6 and T7 while the minimum leaf length (13.6 cm per plant) was found in $0.6 \mathrm{Kr}$ X-rays (T3) treated plants. Among the interactions, the maximum leaf length $(31.8 \mathrm{~cm}$ per plant) was found in $\mathrm{cv}$. 
Suvasini in plants treated with $0.5 \mathrm{Kr}$ gamma rays (T1V3), which was statistically at par with $\mathrm{T} 2 \mathrm{~V} 3$ while the minimum ( $7.9 \mathrm{~cm}$ per plant) was observed in the Kalyani Single treated with $0.6 \mathrm{Kr}$ X-rays (T3V1).

Table 2. Effect of different mutagenic treatments on vegetative characters (contd..)

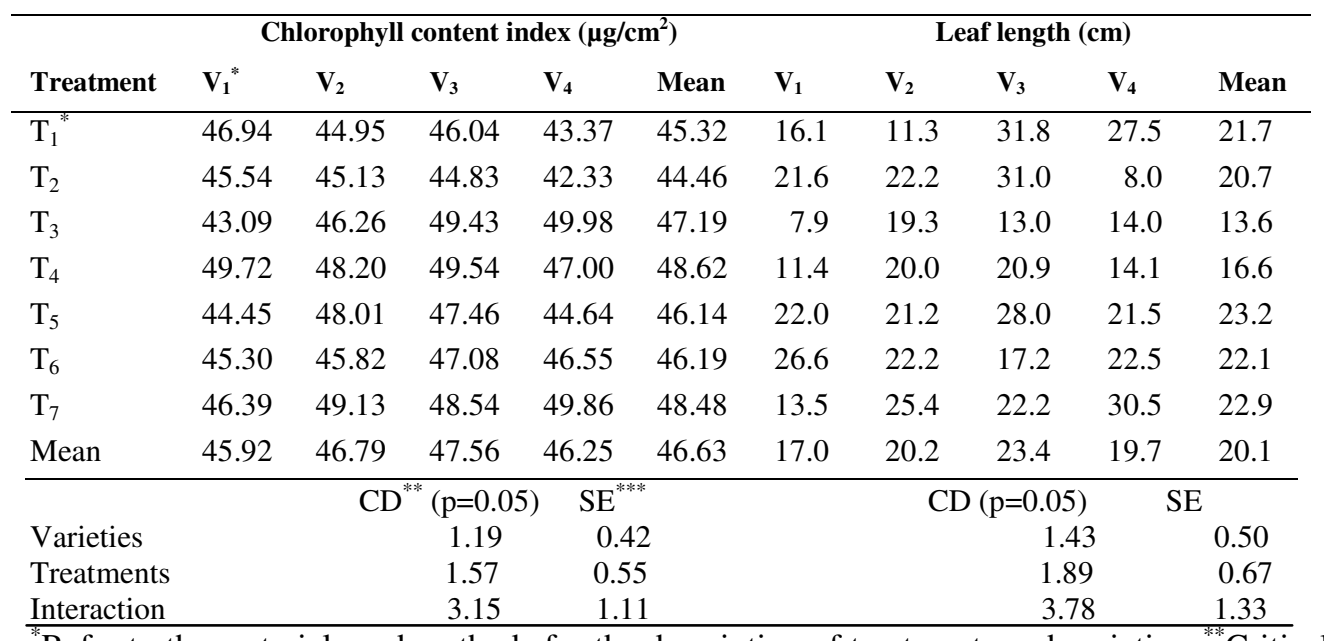

*Refer to the materials and methods for the description of treatments and varieties; ${ }^{* *}$ Critical difference; ${ }^{* * *}$ Standard error of the mean

There was a differential response of cultivars for mutagenic treatments resulting in a nonlinear decrease in leaf length in most of the cultivars when compared to the control, while the EMS and gamma rays treatment resulted in an increase in leaf length in cv. Kalyani Double (V1) and cv. Suvasini (V3). Banerji and Datta (2002), while analysing gamma rays-induced mutation in 'Lalima' chrysanthemum (Chrysanthemum morifolium L.), Dwivedi and Banerji (2008) in gamma induced mutant 'Pinki' of Dahlia variabilis and Dilta et al. (2003) in gamma rays induced mutation in chrysanthemum also reported decrease in leaf length with increase in dose of mutagen.

In Coffea arabica the reduction in leaf length due to X-ray irradiation was associated with abnormalities which are resulting from disturbances by phytochromes (Moh, 1962). Sparrow (1961), while working on cytological effect of radiation, concluded that the decrease in vegetative growth is a result of radiation induced cytological changes such as chromosomal damages, inhibited mitotic division, degeneration of nuclei, cell enlargement, etc.

\section{Floral characters}

A perusal of data presented in Table 3 shows there is significant effect of variety, mutagenic treatment and their interactions on spike length and rachis length. Within treatments, the maximum spike length $(76.1 \mathrm{~cm}$ per plant) was observed in $0.6 \mathrm{Kr} \mathrm{X}$-rays (T3) while the minimum (64.9 $\mathrm{cm}$ per plant) plants treated with $0.6 \mathrm{Kr}$ gamma rays (T1). Among the interactions, the maximum spike length $(89.2 \mathrm{~cm})$ was found in cv. Kalyani Single with 0.2 per cent EMS (T6V1) while the minimum $(54.4 \mathrm{~cm})$ in cv. Kalyani Double with $0.5 \mathrm{Kr}$ gamma rays (T1V2). Karki and Srivastava (2010) who studied the effect of gamma irradiation on various growth and flowering attributes of 20 varieties of Gladiolus grandiflorus also concluded that lower doses i.e. 0.5 and $1.5 \mathrm{Kr}$ was effective in improving some important vegetative and floral parameters. The treatment $0.6 \mathrm{Kr} \mathrm{X}$-rays rays (T3) 
resulted in the maximum rachis length per plant $(29.5 \mathrm{~cm})$ while the minimum $(24.6 \mathrm{~cm})$ was found in plants treated with 0.2 per cent EMS (T6). Among the interactions, the maximum rachis length $(37.1 \mathrm{~cm}$ per plant) was found in cv. Suvasini with control (T7V3) while the minimum (22.1 cm per plant) in cv. Suvasini with $1.2 \mathrm{Kr}$ X-rays (T4V3) [Table 3].

Table 3. Effect of different mutagenic treatments on floral characters

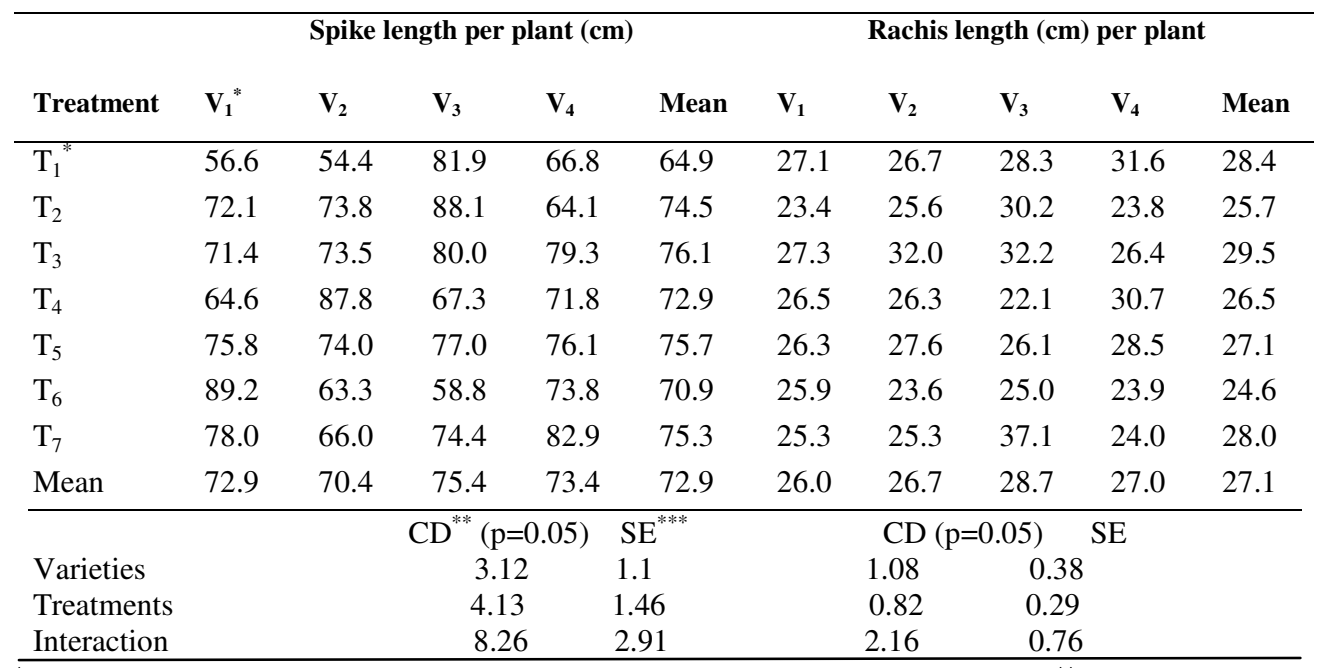

*Refer to the materials and methods for the description of treatments and varieties; ${ }^{* *}$ Critical difference; ${ }^{* * * *}$ Standard error of the mean

A perusal of data presented in Table 4 envisages that floral number is significantly influenced by variety, mutagenic treatment and their interaction. The maximum total number of florets per plant (34.3; Table 4) was recorded in untreated plants (T7) while the minimum (20.9)in $1.5 \mathrm{Kr}$ gamma rays (T2). The maximum number of unopened florets per spike (12.9) was in $0.6 \mathrm{Kr} \mathrm{X}$-rays treatment (T3) while the minimum (8.5) in $1.5 \mathrm{Kr}$ gamma rays treatment (T2). The number of opened florets per spike was the highest (23.71) in untreated plants (T7) while the lowest (12.4) in $1.5 \mathrm{Kr}$ gamma rays (T2). Among interactions, number of total florets per spike was the highest (42.6) in cv. Prajwal with $0.5 \mathrm{Kr}$ gamma rays (T1V4) treatment, while the minimum (13.5) was found in cv. Kalyani Double with $0.5 \mathrm{Kr}$ gamma rays (T1V2). The maximum (17.8) number of unopened florets per spike was found in cv. Kalyani Double with 0.6 Kr X-rays (T3V2) while the minimum (5.2) was found in cv. Kalyani Double with $1.5 \mathrm{Kr}$ gamma rays treatment (T2V2). The number of open florets per spike was the highest (30.9) in cv. Suvasini with $1.2 \mathrm{Kr}$ X-rays treatment (T3V3) while the minimum (7.2) was found in cv. Kalyani Single with 1.5 Kr gamma rays (T2V1) (Table 4). 
Table 4. Effect of different mutagenic treatments on floral characters (contd..)

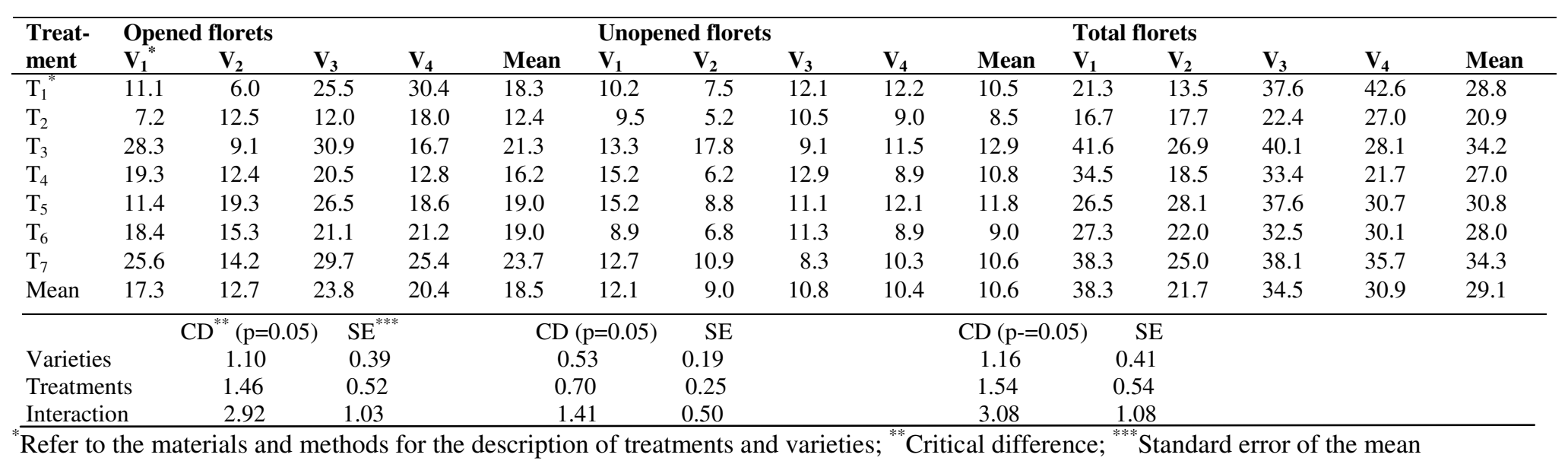

Refer to the materials and methods for the description of treatments and varieties; ${ }^{* *}$ Critical difference; ${ }^{* * *}$ Standard error of the mean 
The flowering duration was significantly affected by mutagen doses $(\mathrm{p}=0.70)$ and their interaction $(\mathrm{p}=0.14)$ with variety (Table 5). The maximum flowering duration (19.2) was observed with $0.5 \mathrm{Kr}$ gamma rays (T1), while minimum flowering duration (12.7 days) was found in 0.2 per cent EMS (T6). Among interactions, maximum flowering duration (28.7 days) was found in cv. Kalyani Double treated with $0.5 \mathrm{Kr}$ gamma rays (T1V2) while minimum (9.7 days) flowering duration was observed in cv. Kalyani Single treated with 0.2 per cent EMS (T6V1), in cv. Prajwal treated with $1.5 \mathrm{Kr}$ gamma rays (T2V4) and 0.2 per cent EMS (T6V4).

A perusal of data for vase life presented in Table 5 envisaged that variety, mutagenic treatment and their interaction affect the vase life of cut spikes. A treatment of 0.1 per cent EMS (T5) gave the maximum vas life (9.5 days) while the minimum (7.5 days) was found in 0.2 per cent EMS (T6). Among interactions, the maximum vas life (13.3 days) was found in cv. Kalyani Single treated with 0.2 per cent EMS (T6V1) while the minimum (5.2 days) in cv. Kalyani Double treated with $0.5 \mathrm{Kr}$ gamma rays (T1V2). Banerji and Datta (2001) also observed a decrease in number of flowers per plants while working with chrysanthemum cultivar 'Surekha'. The decrease in flower head production with higher doses could mainly be due to decrease in plant growth as reported by Dwivedi and Banerji (2008) in dahlia cv. 'Pinki'. Stimulative effect of EMS could be due to its effectiveness to induce a high rate of mutations in both micro and higher organisms. Karki (2008) studied the effect of gamma rays on different varieties of gladiolus and reported that the maximum vase life was observed in $1.5 \mathrm{Kr}$ gamma rays treatment and there was decrease in vase life at higher doses viz., 2.5 and $3.5 \mathrm{Kr}$ gamma rays.

Table 5. Effect of mutagenic treatments on floral characters

\begin{tabular}{|c|c|c|c|c|c|c|c|c|c|c|}
\hline \multirow[b]{2}{*}{ Treatment } & \multicolumn{5}{|c|}{ Duration of flowering (days) } & \multicolumn{5}{|c|}{ Vase life (days) } \\
\hline & $\mathbf{V}_{1}^{*}$ & $\mathbf{V}_{2}$ & $\mathbf{V}_{\mathbf{3}}$ & $\mathbf{V}_{4}$ & Mean & $\mathrm{V}_{1}$ & $\mathbf{V}_{2}$ & $\mathbf{V}_{\mathbf{3}}$ & $\mathbf{V}_{4}$ & Mean \\
\hline $\mathrm{T}_{1}{ }^{*}$ & 12.7 & 28.7 & 19.7 & 15.7 & 19.2 & 7.2 & 5.2 & 10.2 & 10.0 & 8.2 \\
\hline $\mathrm{T}_{2}$ & 11.7 & 23.7 & 15.7 & 9.7 & 15.2 & 8.2 & 6.4 & 11.2 & 8.3 & 8.6 \\
\hline $\mathrm{T}_{3}$ & 14.7 & 21.7 & 22.7 & 16.7 & 18.9 & 6.2 & 9.3 & 8.5 & 9.3 & 8.3 \\
\hline $\mathrm{T}_{4}$ & 10.7 & 18.7 & 17.7 & 11.7 & 14.7 & 8.3 & 10.2 & 11.2 & 8.3 & 9.5 \\
\hline $\mathrm{T}_{5}$ & 12.7 & 18.7 & 15.7 & 13.7 & 15.2 & 12.2 & 11.3 & 7.5 & 9.2 & 9.5 \\
\hline $\mathrm{T}_{6}$ & 9.7 & 22.7 & 12.7 & 9.7 & 12.7 & 13.3 & 8.3 & 7.5 & 9.2 & 7.5 \\
\hline $\mathrm{T}_{7}$ & 15.7 & 21.7 & 21.7 & 15.7 & 18.9 & 7.5 & 8.3 & 7.3 & 9.9 & 8.2 \\
\hline Mean & 12.5 & 18.0 & 18.0 & 13.3 & 16.4 & 9.0 & 8.4 & 9.4 & 9.0 & 9.0 \\
\hline & \multicolumn{3}{|c|}{$\mathrm{CD}^{* *}(\mathrm{p}=0.05)$} & \multicolumn{2}{|c|}{$\mathrm{SE}^{* * * *}$} & & \multicolumn{2}{|c|}{$\mathrm{CD}(\mathrm{p}=0.05)$} & SE & \\
\hline Varieties & \multicolumn{2}{|c|}{0.53} & \multirow{2}{*}{\multicolumn{2}{|c|}{$\begin{array}{c}0.19 \\
0.25\end{array}$}} & & & \multicolumn{2}{|c|}{0.66} & 0.23 & \\
\hline Treatments & \multicolumn{2}{|c|}{0.70} & & & & & \multicolumn{2}{|c|}{0.87} & 0.308 & \\
\hline Interaction & \multicolumn{2}{|c|}{0.14} & \multicolumn{2}{|c|}{$\begin{array}{c}0.25 \\
0.49\end{array}$} & & & \multicolumn{2}{|c|}{0.17} & 0.62 & \\
\hline
\end{tabular}

*Refer to the materials and methods for the description of treatments and varieties; ${ }^{* *}$ Critical difference; ${ }^{* * *}$ Standard error of the mean 


\section{Isolation of Mutants}

Six mutants having desirable variation were found. The desired mutants were:

Mutant 1: A stunted plant with only two whorls of petals was observed in cv. Suvasini in 1.5 Kr gamma-ray treatments (T2V3) (Photo 2).

Mutant 2: A plant having a spike in which lower two florets were fused to form one larger floret was observed in cv. Suvasini treated with 0.2 per cent EMS (T6V3) (Photo 3).

Mutant 3: A plant of cv. Prajwal treated with $1.2 \mathrm{Kr}$ X-rays (T4V4) was having a spike with more than six petal in few florets (Photo 3).

Mutant 4: A plant having a spike in which lower two florets were fused to form one larger floret was observed in cv. Prajwal treated with 0.2 per cent EMS (T6V4) (Photo 4).

Mutant 5: The flower of cv. Suvasini treated with 1.2 Kr X-ray (T4V3) had distinctly visible stamens (Photo 5).

Mutant 6: A plant of cv. Prajwal treated with EMS (0.2 per cent) (T6V4) had extreme reduction in height (Photo 4 ).

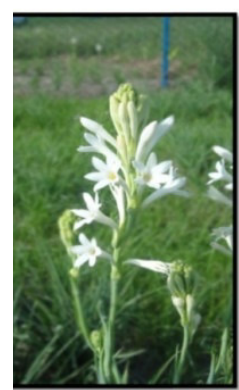

Kalyani Single

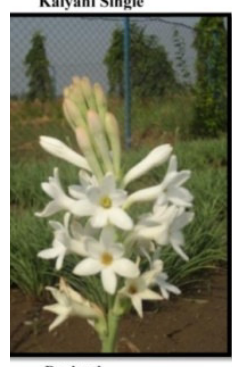

Prajwal

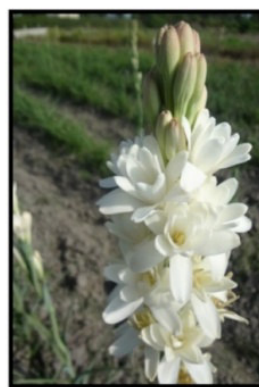

Suvasin

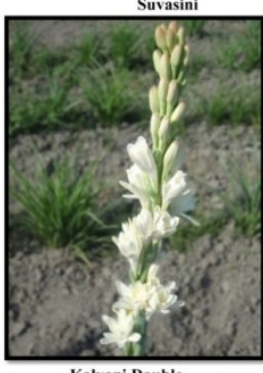

Kalyani Double

Photo 1. Tuberose varieties

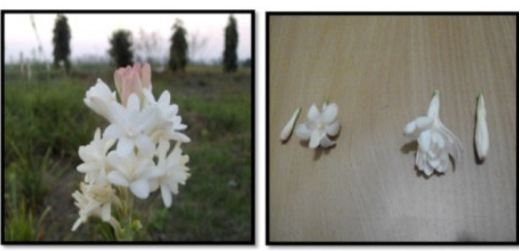

Mutant 1 (With 1.5 gamma rays treatment in cv. Suvasini)
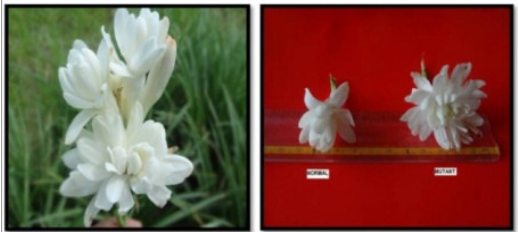

Mutant 2 (With 0.2 per cent EMS treatment in ev. Suvasini)

Photo 2. Mutants of Tuberose cv Suvasini 


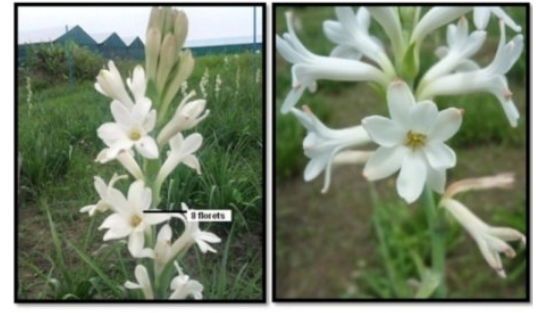

Mutant 3 (With $1.2 \mathrm{Kr}$ X-rays treatment in ev Prajwal)

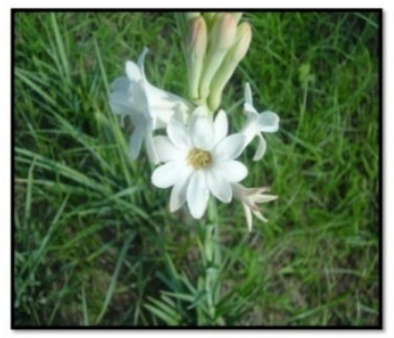

Mutant 4 (With 0.2 per cent EMS treatment in cv Prajwal)
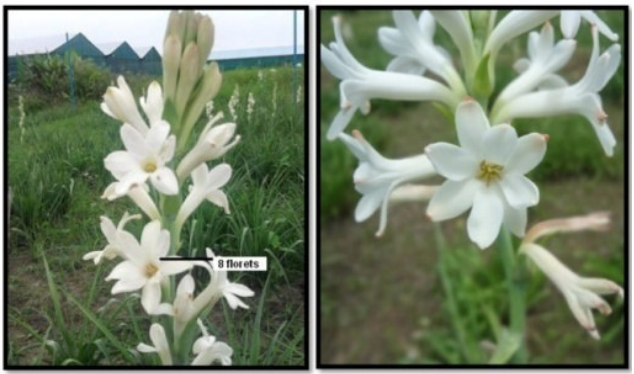

Mutant 3 (With $1.2 \mathrm{Kr}$ X-rays treatment in cv Prajwal)

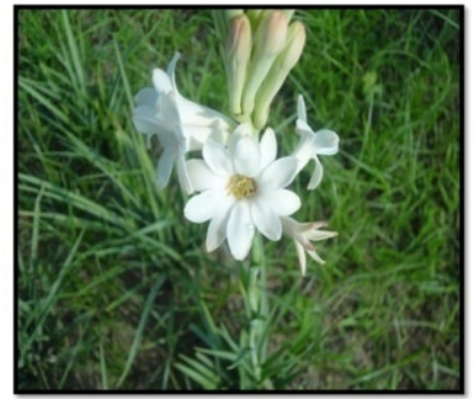

Mutant 4 (With 0.2 per cent EMS treatment in cv Prajwal)

Photo 3. Mutants of Tuberose cv Prajwal Suvasini and Prajwal
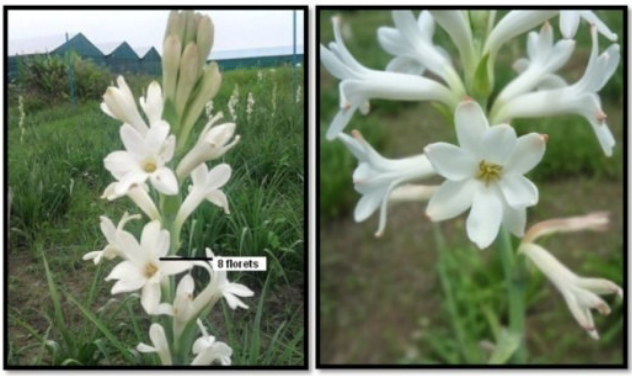

Mutant 3 (With 1.2 Kr X-rays treatment in cv Prajwal)

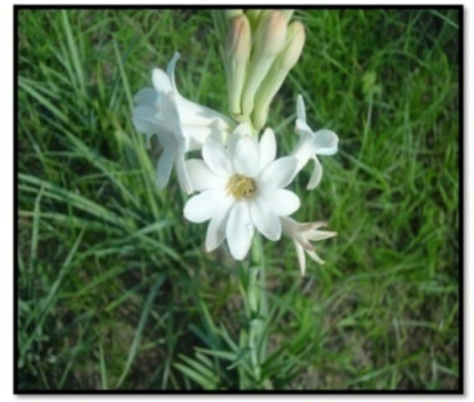

Mutant 4 (With 0.2 per cent EMS treatment in cv Prajwal)

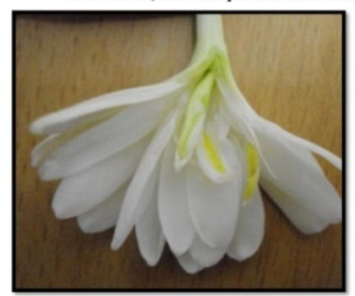

Mutant 5 (With $1.2 \mathrm{Kr} \mathrm{X}$-rays treatment in ev Suvasini)

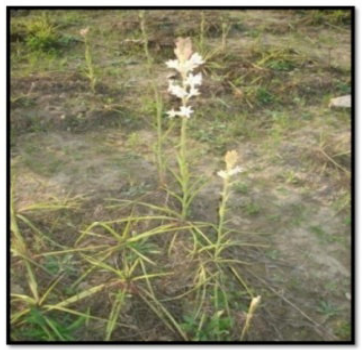

Mutant 6 Mutant (With 0.2 per cent EMS treatment in ev Prajwal)

Photo 4. Mutants of tuberose cvs 


\section{CONCLUSION}

It may be concluded that the lower mutagenic dose $(0.2 \%$ EMS $)$ having stimulative effect on floral characters and being non-detrimental, is beneficial and may be recommended for inducing mutations in tuberose for floricultural traits.

\section{REFERENCES}

Abraham, V. and Desai, B.M. (1976). Biological effectiveness of fast neutrons and gamma rays in some bulbous ornamentals. Indian Journal of Genetics and Plant Breeding, 36(2), 230 $-237$.

Banerji, B.K. and Datta, S.K. (2002) Induction and analysis of somatic mutation in chrysanthemum cultivars 'Surekha', Journal of Nuclear Agriculture and Biology, 30(2), 88 95.

Broertjes, C. 1968. Mutation breeding of vegetatively propagated crops. Proc. $5^{\text {th }}$ Eucarpia Congr. Milan, Italy, pp. 139 - 165.

Datta, P.K. and Datta, C. (1953). High dosage of X-irradiation on inhibition of growth in rice seedlings. Science and Culture, 18, 500 - 502

Datta, S.K. 1997. Ornamental plants: role of mutation. New Delhi, Daya Books, 220p

Dilta, B.S., Sharma, Y.D., Gupta, Y.C., Bhalla, R. and Sharma, B.P. (2003). Effect of gamma rays on vegetative and flowering parameters of chrysanthemum. Journal of Ornamental Horticulture, 6(4), 328 - 334.

Dwivedi, A.K. and Banerji, B.K. (2008). Effect of gamma irradiation on dahlia cv. 'Pinki' with particular reference to induction of somatic mutation. Journal of Ornamental Horticulture, 11(2), 148 - 151.

Fowler, D.B. and MacQueen, K.F. (1972). Effects of low doses of gamma radiation on yield and other agronomic characters of spring wheat (Triticum asetivum) Radiation Botany 12, $349-353$.

Gordon, S.A. and Weber, R.P. (1950). The effects of X-irradiation on IAA and auxin level in plants. American Journal of Botany, 37, 678.

http://www-mvd.iaea.org/FAO/IAEA Mutant Variety Database, MVD/5-5-(2002). August $25,2012$.

Karki, K. (2008). Gamma irradiation studies in gladiolus (Gladiolus grandiflorus L.) Ph.D Thesis, G.B. Pant University of Agriculture and Technology, Pantnagar.

Karki, K. and Srivastava, R. (2010). Effect of gamma irradiation in gladiolus (Gladiolus grandiflorus L.). Pantnagar Journal of Research, 8(1), 75 - 83.

Kolar, F., Pawar, N. and Dixit, G. (2011). Induced chlorophyll in Delphinium malabaricum. Journal of Applied Horticulture, 13(1), 18 - 24. 
Moh, C.C. (1962). The use of radiation induced mutations in crop breeding in Latin America and some biological effects of radiation in Coffee. International Journal of Applied Radiation Isotopes, 13, 467 - 475.

Ramesh, H.L., Yogananda Murthy, V.N., and Munirajappa, P.V. (2012). Effect of gamma radiation on morphological and growth parameters of mulberry variety M5. International Journal of Science and Nature, 3(2), 447 - 452

Sobhana A. and Rajeevan P.K. (2003). Effect of 60Co gamma irradiation on seedling development of Dendrobium. Journal of Ornamental Horticulture, 6(1), 39 - 41.

Sparrow, A.H. (1961). Types of ionizing radiations and their cytogenetic effects. Mutation Plant Breeding NAS-NRC, 891, 55 - 119.

Sreethramu, G.K., Bhat, R.N. and Ranjanna., K.M. (2000). Studies on pollen viability, pollen germination and seed germination in tuberose hybrids and cultivars. South Indian Horticulture, 48(1), 78 - 82 .

Swaminathan, M.S. (1964). A comparison of mutation induction in diploids and polyploids. In: The use of induced mutations in plant breeding. IAEA TechnicalReport, Vienna, pp 619641.

Van Hartan, A.M. (2002). Mutation Breeding of Vegetatively Propagated Ornamentals, pp 105-127. In: A. Vainstein (ed.), Breeding for Ornamentals: Classical and Molecular Approaches. Kluwer Academic Publishers, The Netherlands. 